\title{
Astronomy in Prague: from the past to the present
}

\author{
Alena Hadravová ${ }^{1}$ and Petr Hadrava ${ }^{2}$ \\ ${ }^{1}$ Research Center for the History of Science and Humanities, Academy of Sciences, Prague, \\ Czech Republic \\ ${ }^{2}$ Astronomical Institute, Academy of Sciences, Ondřejov, Czech Republic \\ email: had@pleione.asu.cas.cz
}

Welcome to Prague. Welcome to this Congress Centre built in a close neighbourhood of the ancient seat of the first Czech dukes (Fig. 1). Its name Vyšehrad means the Upper Town. According to the oldest Czech chronicles, it was here where the legendary princess Libuše ordered her people to found the city of Prague and where she envisaged its glory touching the stars (Fig. 2). It was also here where the canon of Vyšehrad recorded in the first half of the 12th century into his chronicle some observed astronomical and meteorological phenomena.

Centuries later, Johannes Kepler, whose results achieved in Prague have really reached a starry fame, reminded Libuše in his treatise Somnium seu De astronomia Lunari, dealing with Lunar astronomy (Fig. 3, cf. Rosen 1967, p. 11): "Stimulated by the widespread public interest, I turned my attention to reading about Bohemia, and came upon the story of the heroine Libussa, renowned for her skill in magic." Kepler's own work is a nice example of links between astronomy and history, which he also studied seriously. He

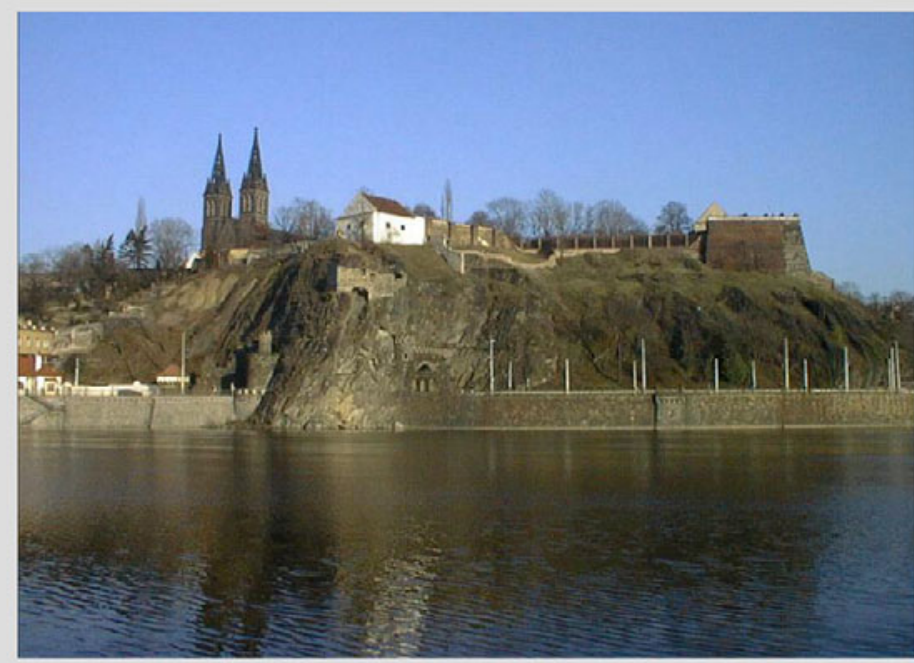

\section{Vyšehrad - the site of medieval castle}

Figure 1. 


\section{Cosmas, Czech Chronicle, 12th century}

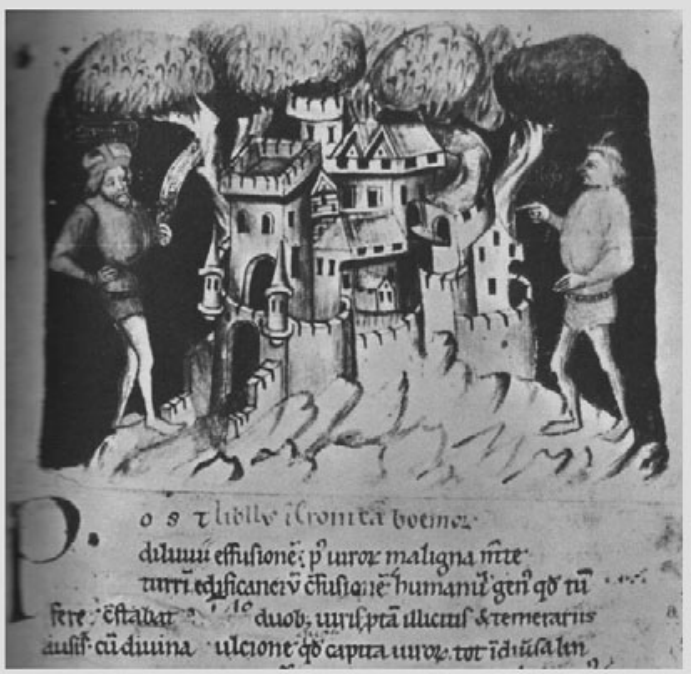

(Prague, National Museum, VIII F 69)

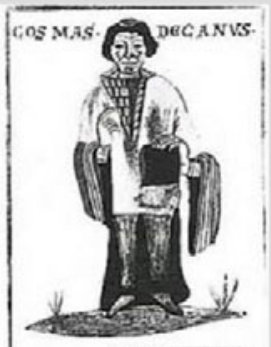

Figure 2.

\section{Johannes Kepler: „Dream or Lunar Astronomy“, 1634 - partly written in Prague}

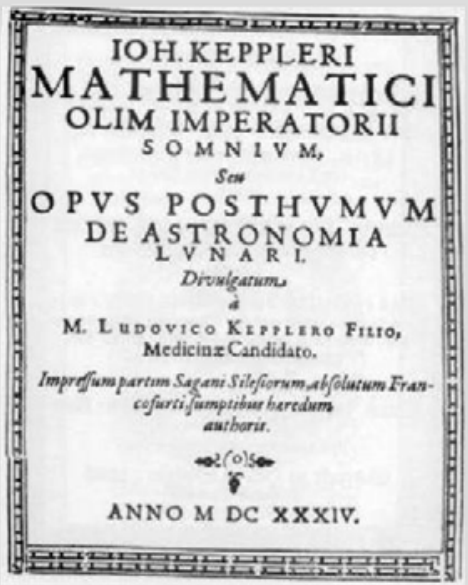

Figure 3.

was searching for historical records of astronomical events and he also judged the impact of astronomical knowledge on the human mind.

Astronomy is not only a science, which is inseparable from other natural sciences and which yields different particular results of practical use, but it is also an important part of culture. 


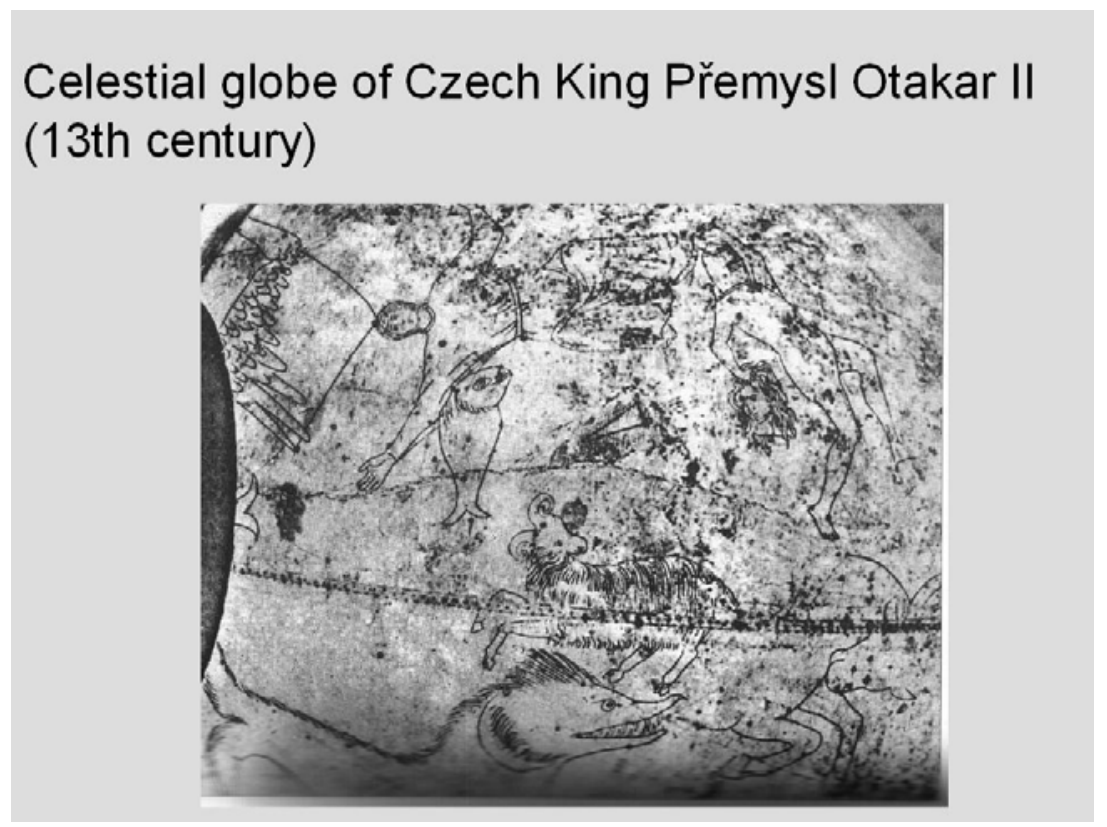

Figure 4 .

It is thus natural that - like in many other countries - astronomy played here this role from prehistoric times. It was cultivated both by the church in monasteries and schools, as well as at courts of nobility in the medieval Czech Kingdom.

Let me show several examples: On the picture we can see the celestial globe from the possession of the Czech King Prremysl Otakar II or Wenceslas II (Fig. 4). It is supposed to be a gift from their relative, the King of Castille Alfonso X the Wise.

Richly illuminated Ptolemaic Catalogue of Fixed Stars written in Northern Italy in the fourteenth century belonged to the collection of astronomical and astrological manuscripts of King Wenceslas IV (Fig. 5). This manuscript follows the tradition of the 9th century Arabian scholar Al-Sufi. For each constellation a table with description of its stars, their coordinates and magnitudes, is accompanied by a figure with the positions of the stars marked.

In another codex from the library of Wenceslas IV we can find a illumination with an astronomer named Těŕiško observing the sky using a quadrant (Fig. 6). This is the first preserved portrait of some Czech astronomer, unfortunately otherwise unknown.

An illustration from the Book of Mandeville's Travels shows astronomers observing stars using quadrants and astrolabes, the most frequently used medieval astronomical instruments (Fig. 7). This Czech work from the early 15th century is nowadays in British Library.

The study of astronomy in Bohemia improved significantly when in the year 1348 the Prague University was established by the Emperor Charles IV as the first one in the Central Europe (Fig. 8). Astronomy reached a high level at the beginning of the 15th century. Among other outstanding scholars of this period was also Master Cristannus de Prachaticz, influential by his works in astronomy, mathematics, medicine and theology. In 1407 he wrote his Composition and Use of the astrolabe as the basis of his university lectures. The astrolabe, a universal astronomical and geodesic instrument, was widely used from Antiquity up to the early modern times. In the Middle Ages, study of the 


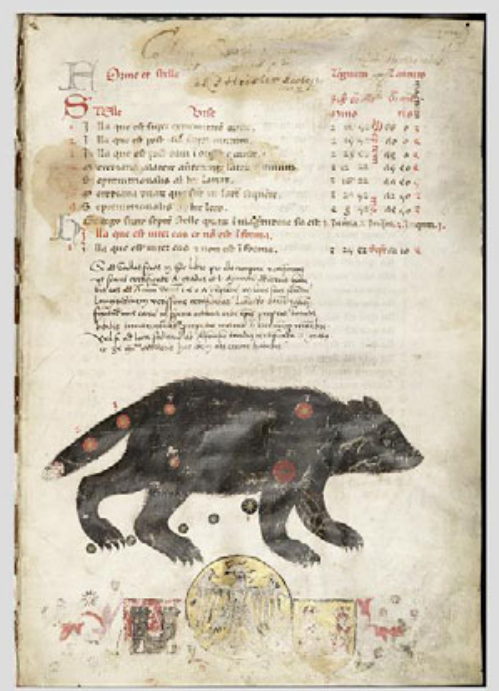

\section{Al-Sufi, Ptolemy's Catalogue of Fixed Stars (14th century)}

(Prague, Royal Canonry of Premonstratensians in Strahov, DA II 13)

Figure 5.

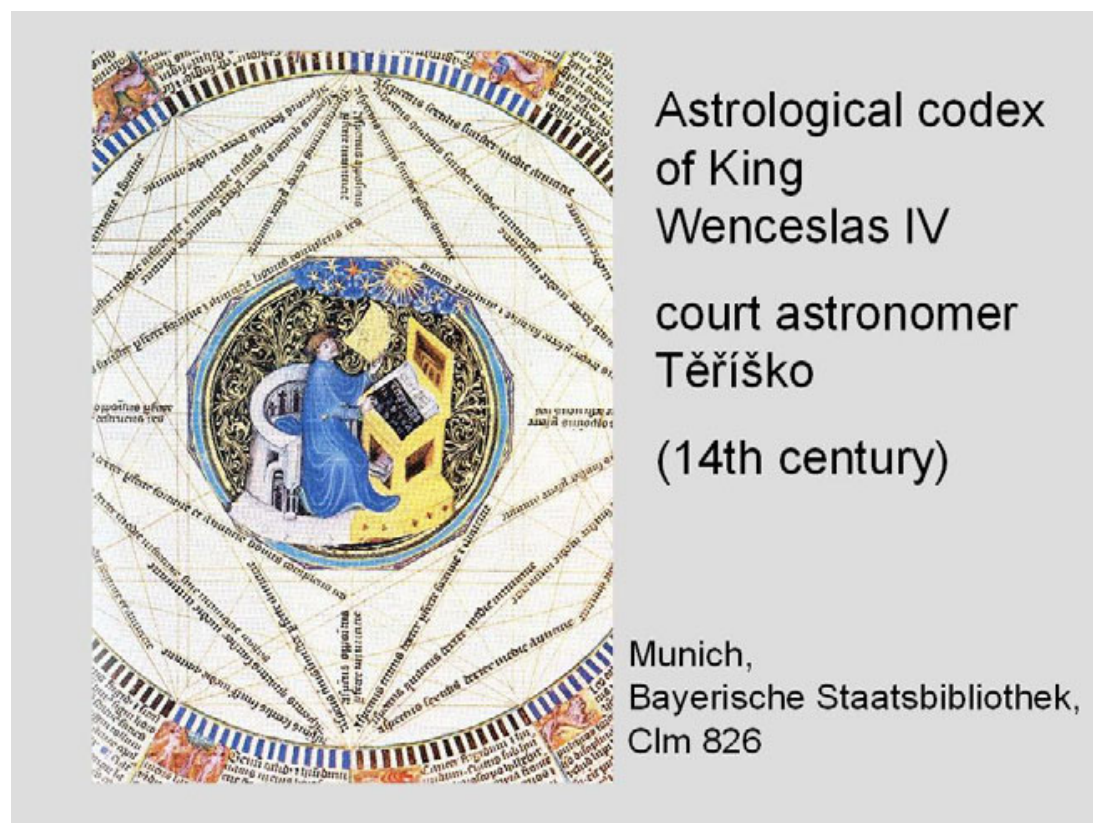

Figure 6.

astrolabe was a fundamental part of the astronomy curriculum in European universities. World literature contains many texts about this instrument, based on Ptolemy's Greeklanguage treatise Planisphaerium (2nd century A.D.). Cristannus's treatises circulated throughout Europe in many copies and later they were also the first printed texts on the astrolabe (the Perugia incunabulum 1477-1479). By tradition, both works were wrongly attributed to Robertus Anglicus or Prosdocimo de Beldomandi until their Prague origin 


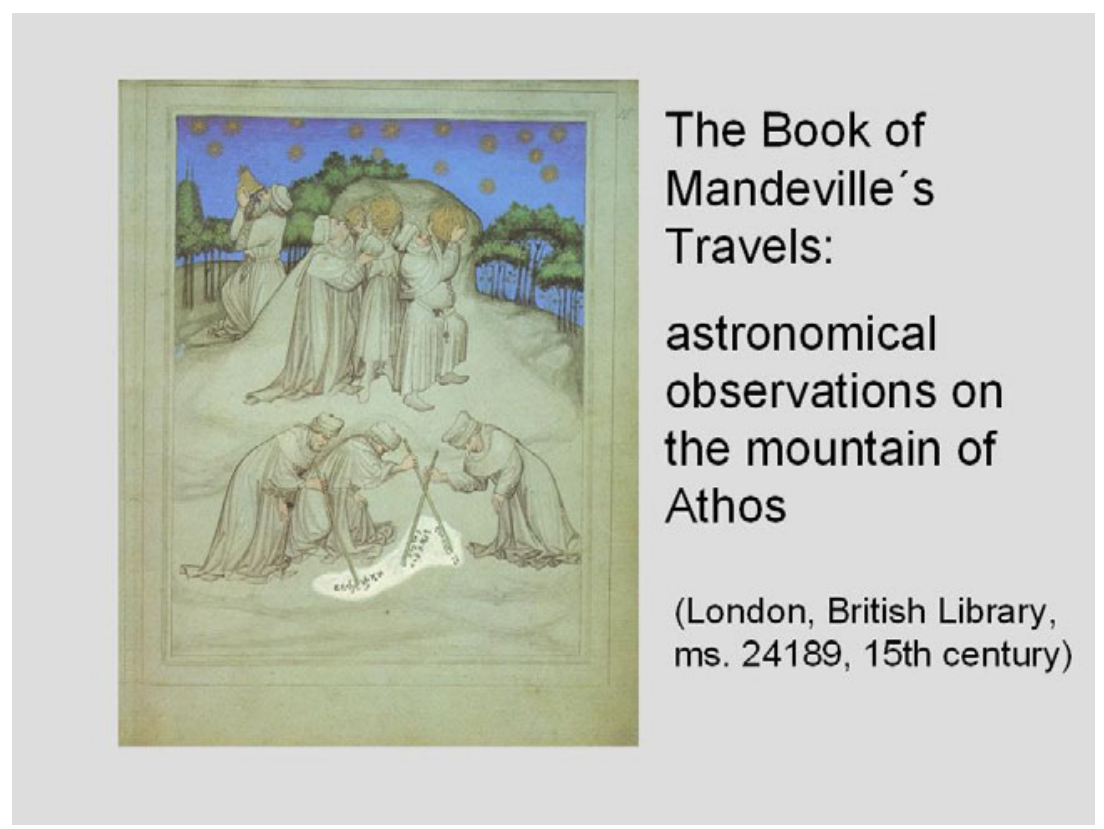

Figure 7.

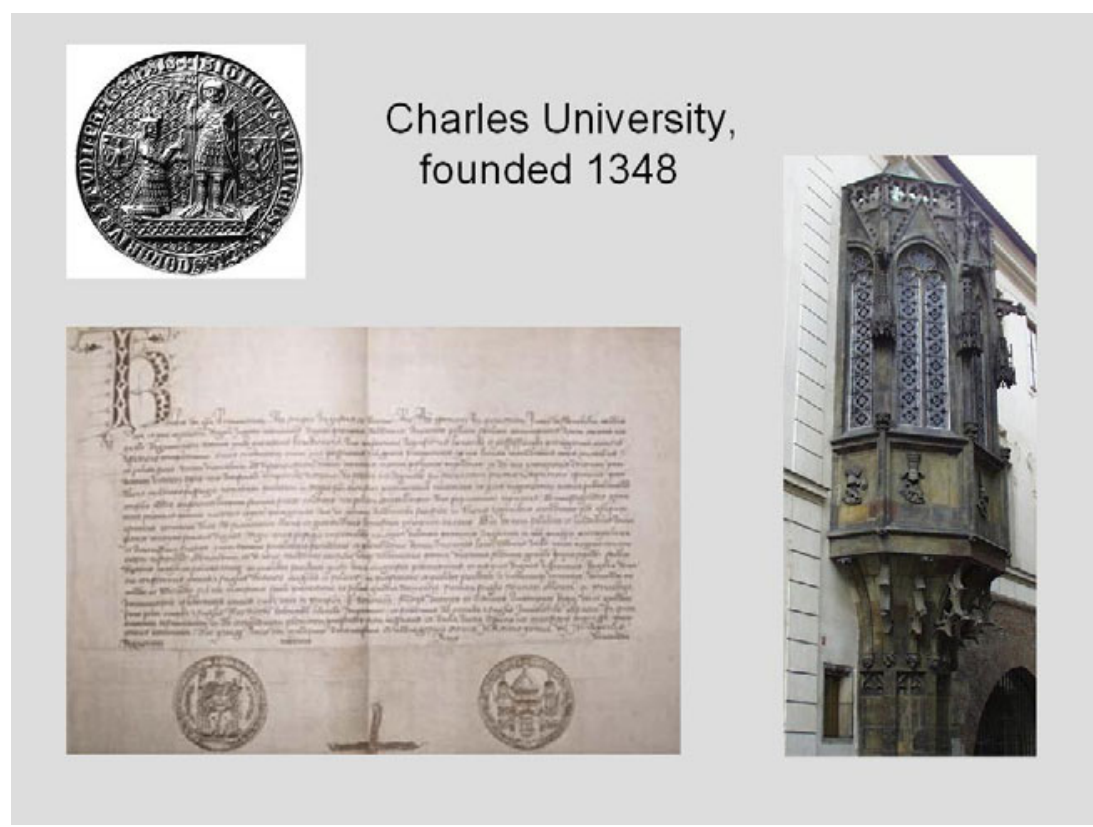

Figure 8.

was proved by the critical edition of the Latin text (cf. Hadravová \& Hadrava 2001, 2007). In the 1420 s or 1430 s, a version of Cristannus' treatises on the astrolabe was written by Master of Viennese University Johannes von Gmunden (the predecessor of Georg von Peuerbach and Regiomontanus at the same university), who borrowed it in its entirety and developed some its passages. 


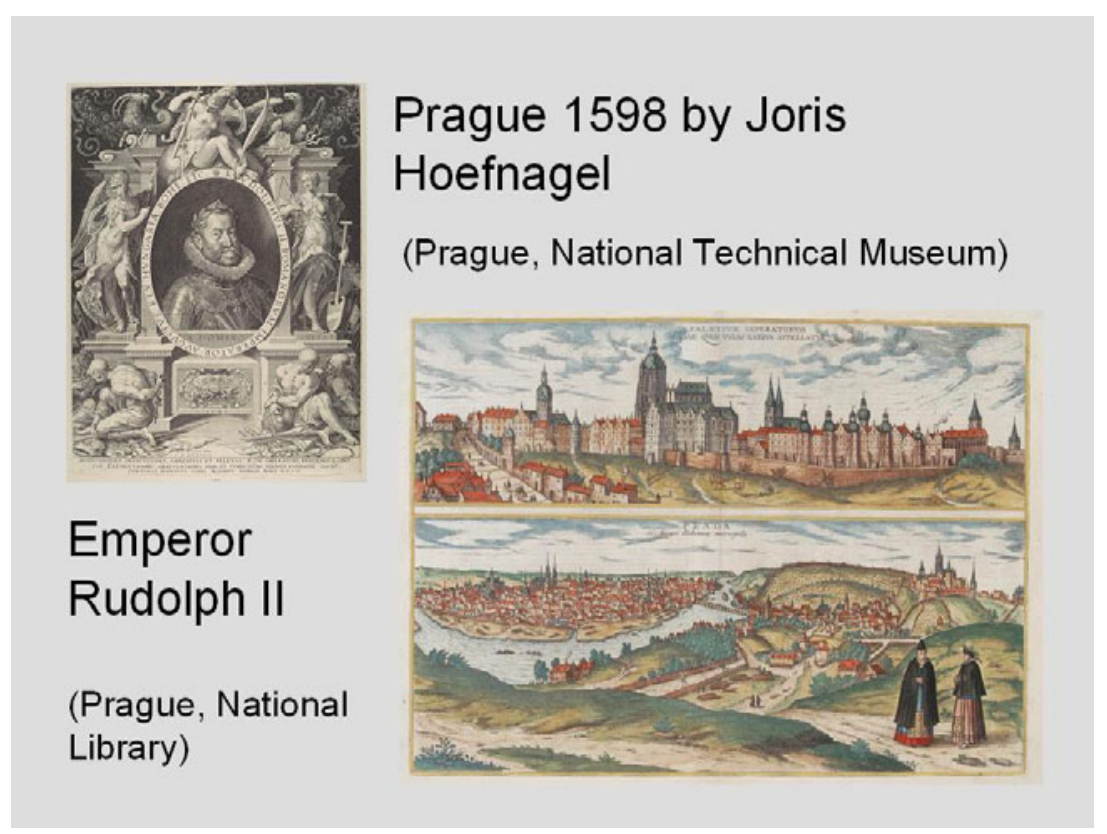

Figure 9.

The importance of Prague as a stage of astronomy culminated in the Rudolphine period at the turn of the 16th and 17th century. Prague was a manifold European cultural center under the rule of the Emperor Rudolph II (Fig. 9).

A prominent Czech scholar Thaddaeus Hagecius observed here the 'new star' of 1572 in the constellation of Cassiopeia. In his treatise Dialexis he proved from the measurement of its parallax the supralunar nature of this object. Hagecius was in friendly relation with Tycho Brahe and being a physician at Emperors court, he used his influence to reach an offer of the position of Imperial Mathematician to the Danish astronomer Tycho Brahe. When Tycho Brahe came to Prague, he invited also Johannes Kepler to work here with him. This promising collaboration of the best observer of that time with the bright theoretician finished soon by Tycho's death in 1601, but Johannes Kepler stayed in Prague for twelve years, which were the most fruitful in his life (Fig. 10). In this period he wrote his main works as Astronomia nova, Optica and others (cf. Christianson et al. 2002). Here in Prague Johannes Kepler also formulated the first two of his laws of planetary motion.

Instruments made by famous mechanicians on the Prague Imperial court like Erasmus Habermel or Joost Bürgi are preserved in National Technical Museum as well as in many museums all over the world (Fig. 11, cf. Horský \& Škopová 1968).

In the epoch of re-catholicization after the Thirty Years War (1618-1648) the education in Bohemia was dominated by the Jesuit order established in 1540. Jesuits also cultivated science, including the astronomy (cf. Kašparová \& Mačák 2002; Voit 1990). They came to Prague already in 1556 and in the middle of the 17th century they started to build the Clementinum college - a monumental complex of buildings. Owing to a frequent migration of Jesuits from one college to another or to missions, several skilled astronomers and mathematicians were professors in Clementinum or got their education here and worked later abroad. Among others, let us name Roderigo de Ariaga, Theodore Moretus, Valentin Stansel, François Noël, Karel Slavíček, Johann Klein, Joseph Stepling, 


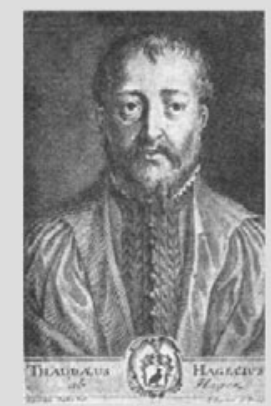

\section{Tycho Brahe}

Thaddaeus

Hagecius

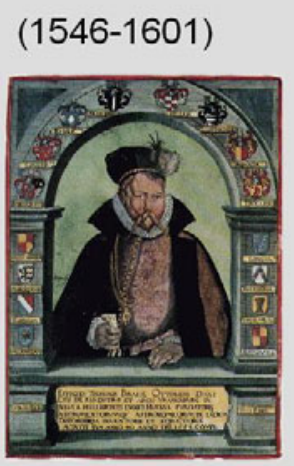

Johannes

Kepler

(1526-1600)

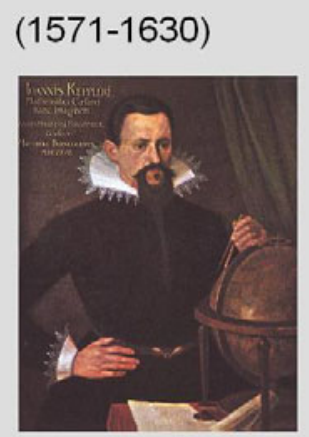

Figure 10.

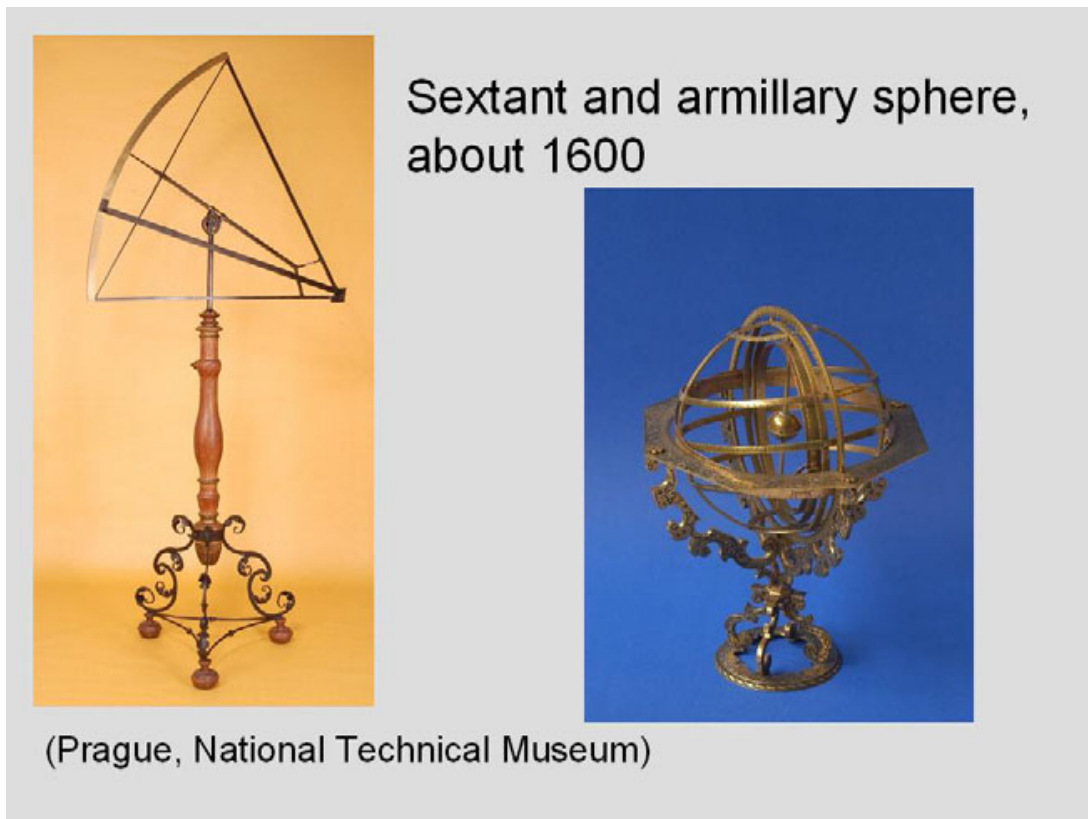

Figure 11.

Antonín Strnad or the premonstratensian Alois David. In spite of their overridingly ideological mission, Jesuits in Prague were relatively tolerant with respect to heliocentrism and related opinions, what is testified by some their writings as well as by frescoes in Clementinum, which show as comparable theories the Ptolemy's, Copernicus', Brahe's and Riccioli's model of the Solar System, or even the Giordano Bruno's multiplicity of the worlds. 


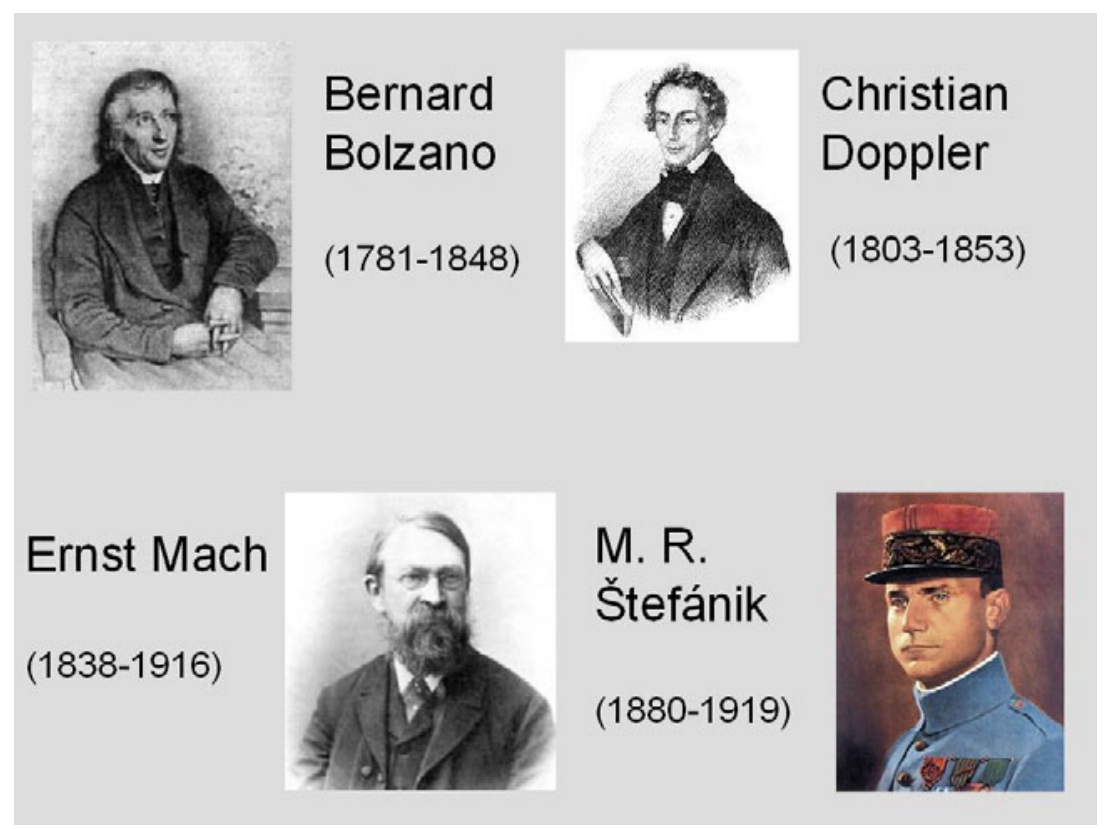

Figure 12.

Several achievements in astronomy, mathematics and physics were also reached here later on at the time of the Austrian Empire. For instance the mathematician and philosopher Bernard Bolzano (Fig. 12) dealt with theory of functions, mathematical logics and analysis. Christian Doppler gave the first lecture on his principle in Karolinum, the historical central building of Charles University, in 1842 and he published his attempt to explain differences in colours of some binaries by difference of their radial velocities in Proceedings of the Royal Czech Learned Society (cf. Štoll et al. 1992). Ernst Mach was a professor of experimental physics at Prague university for three decades. He made here his experiments in acoustics and optics, including a study of shock waves generated by supersonic motion (cf. Janta \& Niederle 2005). Astronomy was also one of the sciences promoted by Czech patriots during their effort at cultural, economical and political emancipation of Czech nation - let me name Josef Jan Frič, the founder of Ondřejov observatory, as example. The work of Slovak astronomer Milan Rastislav Stefánik, who studied in Prague, turned out to be crucial in establishing of Czechoslovakia.

A review of history of astronomy in Bohemia as well as of its present status can also be found in the book by Hadrava (2006).

Prague is said to be a city of a hundred towers. Allow me to remind you of three of them, which are connected with astronomy:

The first one is the tower of Charles Bridge on the Old Town side (Fig. 13). It was founded by the Emperor Charles IV as his triumphal arc at a unique event - in 1357 on the 9 th of July at 5:31 in the place, from where the summer solstice sunset is seen behind the tomb of St. Vitus in the cathedral at Prague Castle. The importance of this structure is also emphasized by medieval cosmological model encrypted in its decorations individual layers correspond to spheres of the Earth, Moon, Sun and stars (cf. Horský 1979).

The second tower at the Town hall on the Old Town Square is equipped by horologium the famous Astronomical clock of Prague (Fig. 14). It was constructed in 1410 by clock- 


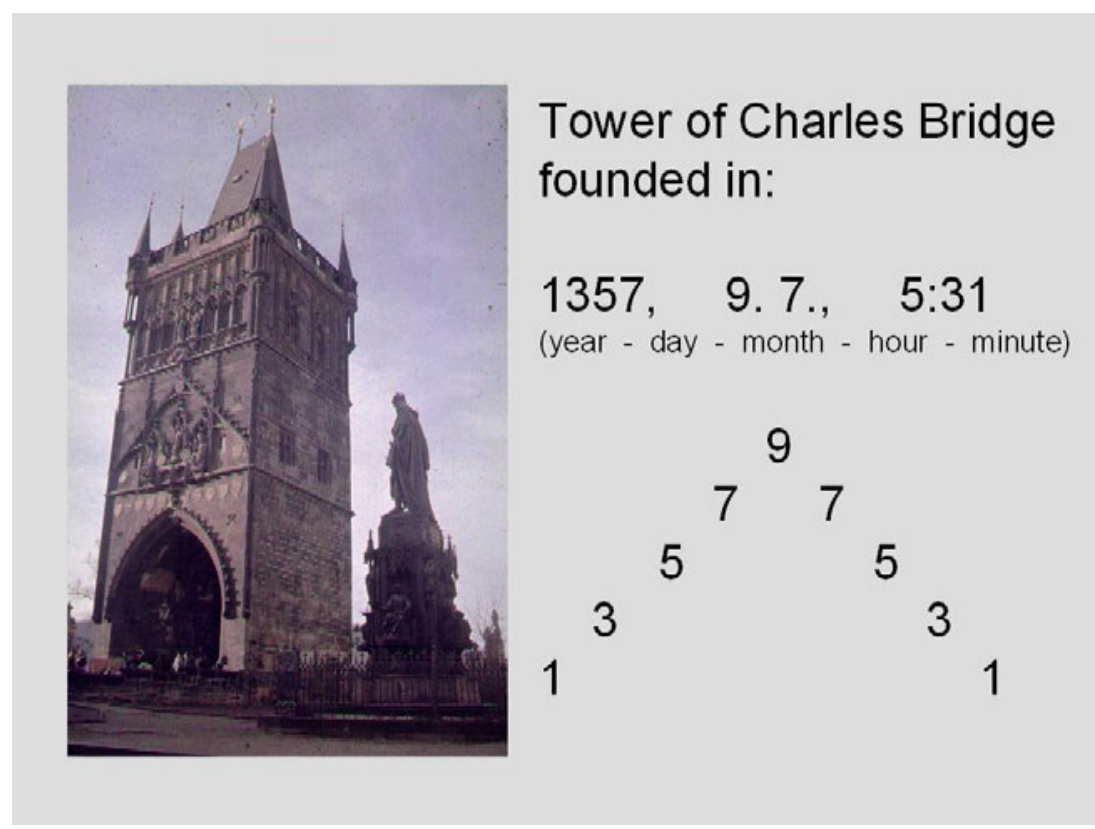

Figure 13.

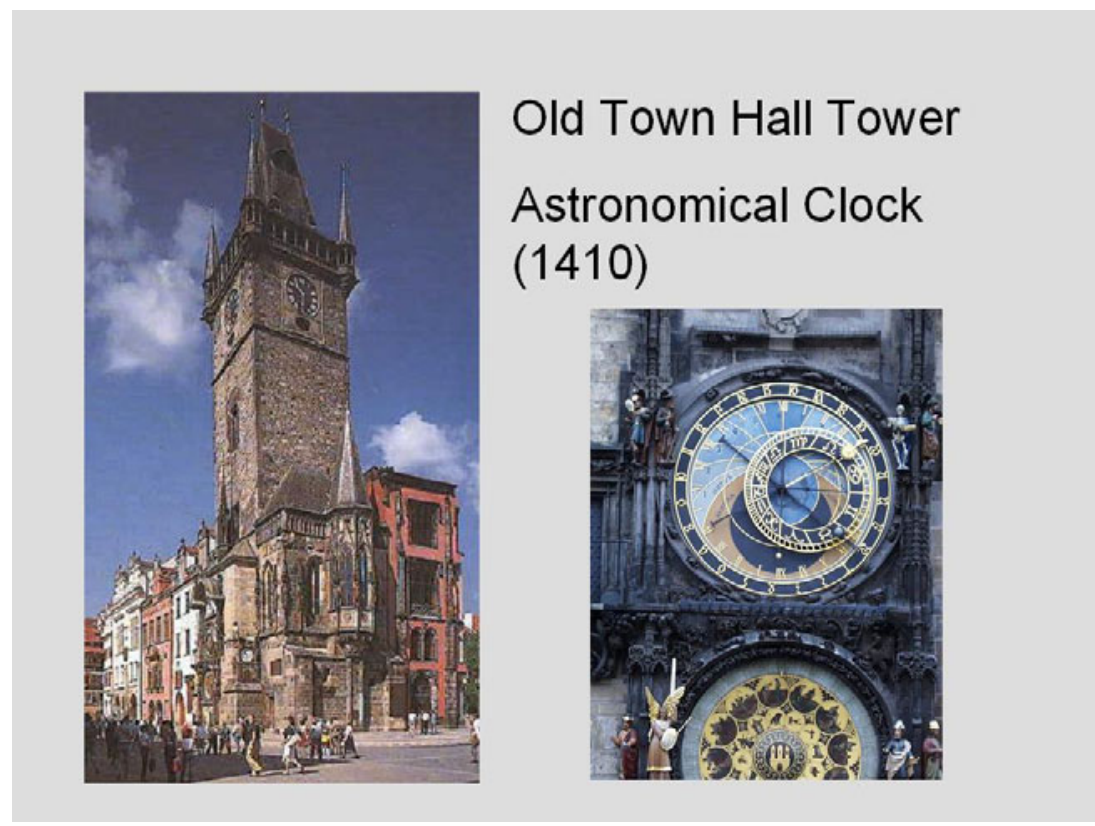

Figure 14.

maker Mikuláš of Kadaň according to recommendations of the Master of Prague university Iohannes Šindel, to use the then astronomical knowledge for practical purposes of time-keeping. Its dial is an astrolabe, which shows the position of Sun and Moon on the ecliptic, as well as the position of the ecliptic with respect to the horizon of Prague. It enables to read not only the nowadays commonly used equal hours, but also the unequal 


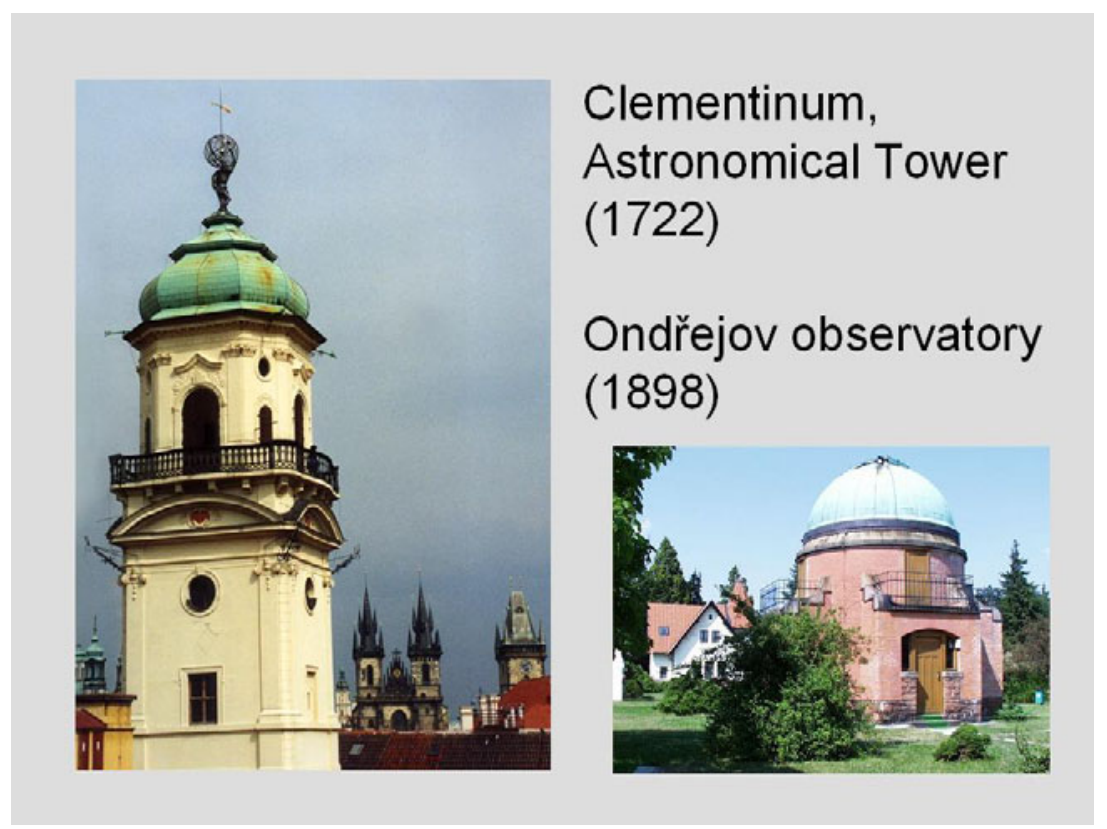

Figure 15.

hours dividing the time from sunrise to sunset into twelve equal parts, as well as the old Czech time measured from the sunset and the sidereal time. The horologium still runs with the original gothic clockwork (Horský 1988).

Finally, the third tower, which you know from the poster of this General Assembly, is the Astronomical observatory of Jesuit college Clementinum erected in 1722 (Fig. 15). Its purpose was not only to measure the time with increasing precision, but also to contribute to the development of astronomy itself (cf. Síma 2006). When the Jesuit Order was dissolved in 1773, the Astronomical tower became the Czech state observatory. Its tradition continues to the present day, and is developed by its follower, the Astronomical Institute of the Academy of Sciences of the Czech Republic, which gradually moved into its new seat in the astrophysical observatory at Ondřejov.

These three examples illustrate different historical roles of astronomy: as a symbol in culture and arts, a tool in daily practice, and an advanced science challenging the human mind and promoting its development. The present day sciences tend to diverge into many narrow fields, which are nearly inaccessible to non-specialists. However, an important feedback to the general culture persists. This is again remarkably seen in astronomy.

For instance, one of subjects of this meeting is the physics of black holes, the historical roots of which lead to Albert Einstein acting in Prague nearly a century ago (Fig. 16). Mathematical details of this subject are similarly difficult for layman as the systems of epicycles centuries ago. Nevertheless, basic notions and results have already became a part of common knowledge.

At the end of my talk, I would like to wish you for your coming meeting a great success in revealing new secrets of the Universe. And at the same time, I wish to the public to get from you a new enlargement of the horizons of mind. Thank you for your attention. 


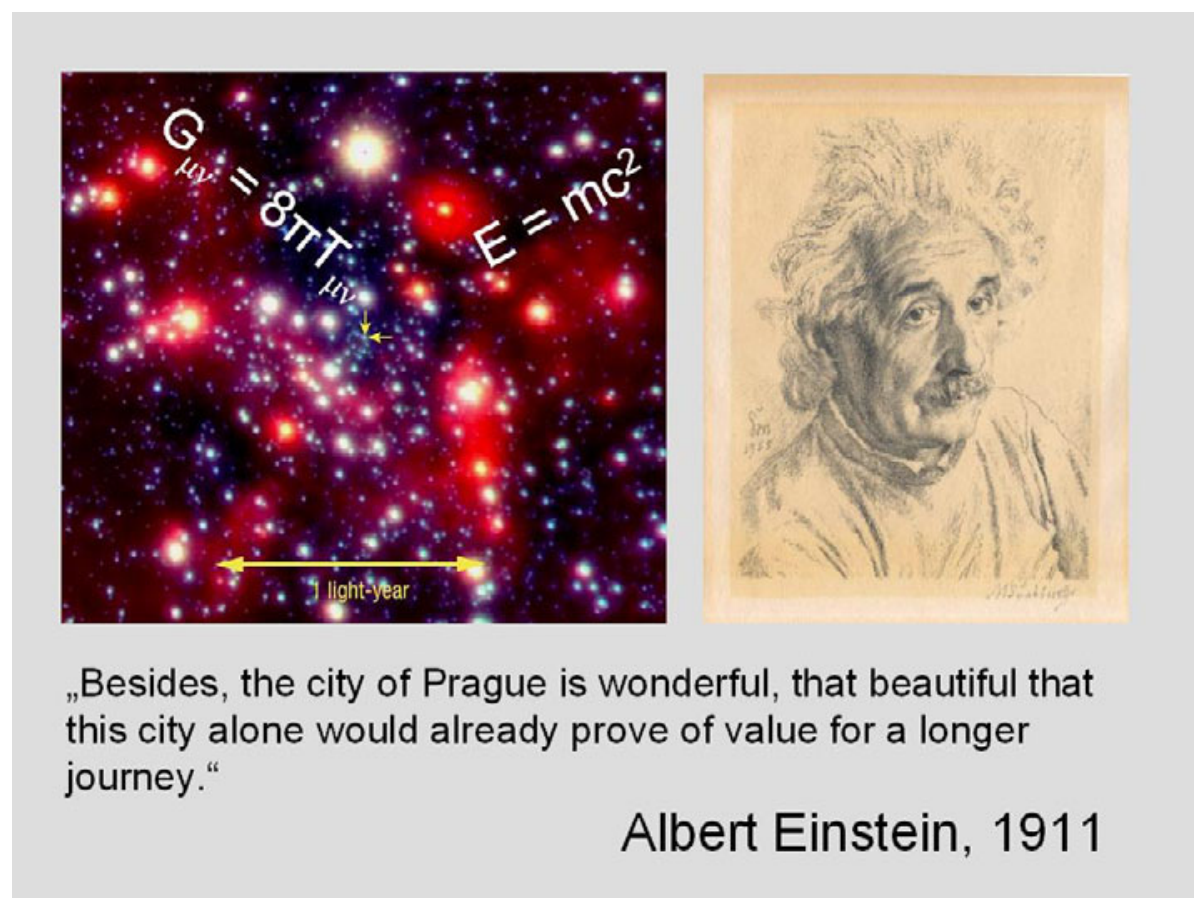

Figure 16.

\section{References}

Christianson, J. R., Hadravová, A., Hadrava P., \& Šolc, M. (eds.) 2002, Tycho Brahe and Prague: Crossroads of European Science, Acta Historica Astronomiae, vol. 16 (Frankfurt am Main: Harri Deutsch Verlag)

Hadrava, P. 2006, The European Southern Observatory and Czech Astronomy (Prague: Academia)

Hadravová, A. \& Hadrava, P. 2001, Křištan z Prachatic, Stavba a Užití astrolábu (Prague: Filosofia)

Hadravová, A. \& Hadrava, P. 2007 - in press, Prachaticz, Cristannus de. In: Dictionary of Scientific Biography (New York: Charles Scribner's Sons)

Horský, Z. 1979, Založeni Karlova mostu a kosmologická symbolika Staroměstské mostecké věže. In: Staletá Praha (ed. Z. Buříval), vol. 9 (Prague: Panorama), pp. 197-212

Horský, Z. 1988, Pražský orloj (Prague: Panorama)

Horský, Z. \& Škopová, O. 1968, Astronomy Gnomonics. A Catalogue of Instruments of the 15th to the 19th Centuries in the Collections of the National Technical Museum (Prague: Panorama)

Janta, J. \& Niederle, J. (eds.) 2005, Physics and Prague (Prague: Academia)

Kašparová, J. \& Mačák, K. 2002, Utilitas matheseos. Jesuit Mathematics in the Clementinum (1602-1773) (Prague: National Library)

Rosen, E. 1967, Kepler's Somnium. The Dream or Posthumous Work on Lunar Astronomy (Madison, London: The University of Wisconsin Pess)

Šíma, Z. 2006, Astronomy and Clementinum (Prague: National Library)

Štoll, I., Seidlerová, I., Schwippel, J., Pöss, O. \& Šolc, M. 2006, The Phenomenon of Doppler (Prague: The Czech Technical University)

Voit, P. 1990, Pražské Klementinum (Prague: Národní knihovna)

[Extended version of lecture read by Alena Hadravová at the Inaugural Ceremony of the IAU XXVI General Assembly, Prague, 15 August 2006.] 